\title{
Animals, Arrogance and Unfathomably Deep Ecology
}

\author{
Tal Scriven \\ University of Colorado and \\ California Polytechnic State University \\ at San Luis Obispo
}

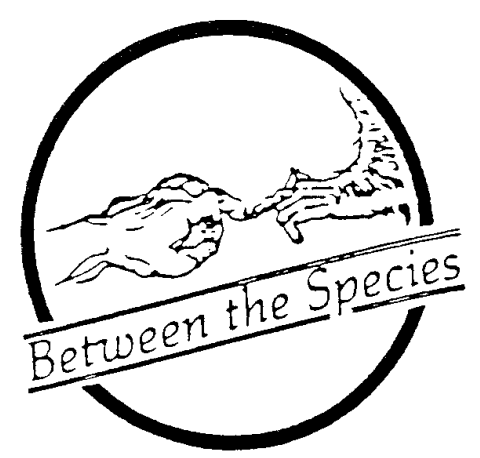

Editors' Note: The following article by Professor Scriven and a reply by Professor Susan Finsen (unavailable at present) were presented at the Pacific Divison meeting of the Society for the Study of Ethics and Animals, held in Portland, Oregon, March 26, 1992.

The clash between environmentalists and animal liberationists was summarized a few years ago by the title of Mark Sagoff's article "Animal Liberation and Environmental Ethics: Bad Marriage, Quick Divorce."1 The problem, of course, is not environmental ethics per se but a certain kind of environmental ethics, namely, what has come to be called "deep ecology" (as well as "biocentrism," "ecocentrism" and "the land ethic"). For the deep ecologist, environmental issues must be looked at from a fully holistic perspective, that is, from the point of view of the whole biosphere. At first, this would seem to be a natural extension of our basic moral sentiments. Having established the moral considerability of all humans and then all mammals and then all living individuals, the next logical step would seem to be an extension of our moral concern to the biosphere as a whole.

But, as was soon recognized, the holism of deep ecology cuts directly against any strong concern for the pain and suffering of individual animals; from the biocentric point of view, the concern of animal liberationists for the welfare of individual animals, is "biologically preposterous," to use J. Baird Callicott's term. ${ }^{2}$ The integrity of the biosphere is underpinned

largely by a cycle of eating and being eaten which cannot and should not be interfered with because of a passing squeamishness in a few humans. Are we, after all, to intervene on behalf of a rodent to insure that its rights are not violated by any condors?

This appeal to the necessity of predation in the natural order of things is, of course, familiar rhetorical territory for animal liberationists. They are quite used to hearing about the hunter instinct from people who do all of their hunting at Safeway (as though something of great ecological import hinges upon the production of cube steak and little styrofoam trays). Rhetoric aside, the central misgivings of animal liberationists were given voice several years ago by Tom Regan. ${ }^{3}$ In the first place, the holism of the deep ecologists threatens us with a kind of "environmental fascism" which would require the merciless extermination of animals and, particularly, humans for the good of the greater biotic whole. Secondly, it is utterly unclear how anything below the conative level of animals can be sensibly argued to have any interests and, thus, any good of its own. The attribution of sentience to plants and rocks (let alone whole ecosystems) seems to be something best left to the editors of the National Enquirer, and if such things can't have beliefs, desires and feelings, then how can they have any good apart from that attributed to them by sentients? In other words, there is an immediate problem with any claim

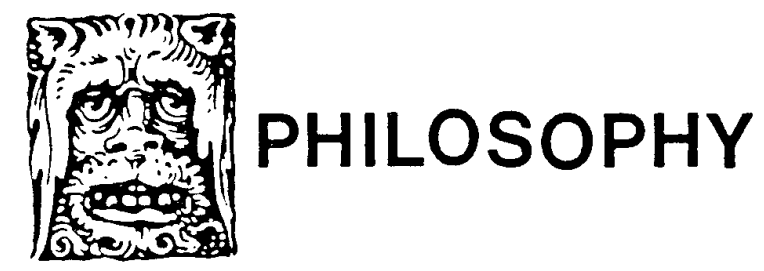


that we ought to adopt some biotic perspective inasmuch as the biosphere does not appear to be the kind of thing that can have a perspective.

What was not recognized by Regan was that these two lines of criticism are antithetical. If the biosphere cannot have a good of its own, then nothing could be sacrificed for that good. For the sake of clarity, animal liberationists must make up their minds about how they ought to face off against the ecocentrists. It is the point of this paper to argue that they (and everyone else) ought to reject the idea that nature as a whole has any interests or good unto itself. I shall survey many of the arguments that have been used to establish ecocentric positions and argue that they all lead to an ecology which is unfathomably deep.

As a first approach to the issue of what can and cannot have interests, let us consider the arguments of R. G. Frey and Pàul Taylor. Neither of these writers is a full-blown holist (although Taylor is close). For both, the immediate concern is the attribution of intrinsic value to individual nonsentients (although Frey is interested in such an attribution only for the sake of showing that it doesn't amount to much). Nevertheless, it would seem as though the question about nonconative individuals will stand or fall with the one about nonconative wholes. Whether we are talking about individual trees, whole forests or whole planets, the basic mystery is how anything can have a good of its own without being the subject of some kind of desire or end in view.

Frey's argument is that, although nonconative things may not be able to have an interest in anything, there may still be things which are in their interests. Although trees and tractors may not have an interest in, respectively, maximal growth or proper maintenance, these things may really be in the interests of trees and tractors. ${ }^{4}$ Similarly, Taylor argues that, "we can act in a being's interest or contrary to its interest without its being interested in what we are doing to it in the sense of wanting or not wanting us to do it." 5 This line of argument is profoundly unsatisfactory. Who are we to say what the interest of a tree is? In the case of the tractor, we will generally assume that it is supposed to perform certain functions for which it was expressly designed. And even here there are problems, for I might buy a tractor for the usual reasons or I might buy one specifically to let it rust and sit in my yard as a sculptural statement about something. If I wanted it as sculpture then I would not be surprised if someone suggested that
I was not doing with the tractor what was supposed to be done with it, because this only implies that I would not be doing with it what is usually done with tractors. But I would be quite surprised if someone claimed that I was not acting in the best interests of the tractor. I would understand someone saying that I was wasting a piece of machinery that other humans might make better use of, but what difference could any of this possibly make in terms of what is good for the tractor?

However, in the case of trees, things are even worse. Both Frey and Taylor argue that it is clearly not in the interest of a tree to bulldoze it down, perhaps, for later conversion into a coffee table; its interest is in "flourishing." But here, an obvious piece of questionbegging is at work. What it means to flourish is, roughly, to develop in the right way, and what is at stake here is the issue of whether or not it is right for us to develop the tree into a coffee table or into mulch. When called upon for a foundation for the claim that the right way for a tree to develop is to "flourish" (i.e., to have lots of leaves and seeds at certain times, reach a maximal height or width, whatever) Taylor gives us the following claim: "We can think of the good of an individual nonhuman organism as consisting in the full development of its biological powers." But the "biological power" of any tree is for it, ultimately, to become mulch or ashes. Moreover, if we are to avoid the "arrogance" of thinking of ourselves as being outside of nature, then the fact that many trees wind up as coffee tables means that the "biological power" of many trees is to become coffee tables.

Things are not improved one bit by going deeper into the history of philosophy to find a foundation for an environmental ethic. Robin Attfield, for example, eventually fesses up to an underlying "Aristotelian principle" beneath the attribution of interests to nonsentient beings. Following Clark, ${ }^{7}$ Attfield pegs the neoAristotelian telos of a thing as "the proper fulfillment of [its] genetically programmed potentialities." ${ }^{8}$ What is "neo" about this neo-Aristotelianism is not just the mention of genetic programming but, more importantly, the fact that tele are attributed to nonsentients on the basis of their own ends whereas Aristotle held that the good of plants had to be understood in terms of the good of animals which, in turn, had to be understood in terms of the good of humans. By reducing all teleological concerns to humans, Aristotle avoids the obvious problem with Attfield's position, namely, that, in choosing among the ends that befall trees, we are 
being profoundly presumptuous in claiming to know that the "proper" end of a tree is to have a maximal height or width rather than to be mulch, ashes or a coffee table; nature dictates no one of these ends over the others.

Things only get worse when we abandon the individualistic approaches of Frey, Attfield and Taylor ${ }^{9}$ and move toward the holism of Callicott, Leopold, Rodman, Stone and others. Here, the problem of arrogant presumption is simply moved to a different level. Rather than claiming that they know what is good for a tree, they go on to claim knowledge of what is good for the whole of the planet-even absent any indications from the planet itself. The move from individualism to holism, of course, does nothing but compound the arrogance of those who claim to know what's good for individual trees, carrots or rocks. To make a long argument very short, I submit that if we humans were to explode fifty thousand nuclear devices on the face of this planet tomorrow, there would be no tolerably clear sense in which we have "hurt nature" (beyond that hurt felt by sentients on this planet). Eventually, some organisms would survive and even thrive in the new order of things, and others would perish-such is life. Indeed, biological diversity would not likely be as great, because the most likely victims of the radiation would be mammals, birds and other predators who play a central role in diversification of species. Indeed, the "beauty of the biotic community" may suffer, but that will be because there will not likely be any creatures around who have any sense of beauty. ${ }^{10}$

The use of the word "arrogance" in the last few paragraphs will not be seen as gratuitous by anyone who has looked at the literature on environmental ethics. Generally, what deep ecologists have seen as the principle cause of our current environmental problems is an arrogance about our relationship to nature that comes out of not only the Judeo-Christian tradition but also the Greco-Roman tradition and the European Enlightenment. ${ }^{11}$ The way to combat such arrogance, it seems to me, is to realize our profound ignorance about how nature works and, accordingly, to adopt an extreme conservatism in our dealings with a biological leviathan that has the capability of retaliating with a vengeance when we make apparently minor but irreparable alterations in the biosphere. The course of the deep ecologists seems, paradoxically enough, to base environmental concern on an assumption that we not only know how nature works but, also, how it ought to work. They explicitly go beyond what's good for us to claims about what's good for it, as though they, like the Christians, know why nature is here. Moreover, there is another level to my uneasiness about their general line of argument caused by the constant intrusion of neo-Aristotelianism and, more pertinently, neoThomism into their writings. As Passmore points out, the Judeo-Christian tradition does not unequivocally lead to the position that the earth is here to do with as we please. The earth is here as a consequence of God's benevolent and omniscient design and creation. If, then, nature is of God's design, we should not seek to alter the natural course of things. This, of course, is not fully (if at all) compatible with much of Genesis, but it does allow the Judeo-Christian to hold the general ideology that we should think of ourselves as stewards of the earth rather than as despots over it.

What is especially troublesome with this idea that to alter the natural course of things (where "natural" usually is taken to mean "without human intervention") is sacrilegious is, of course, that it is behind a pernicious traditionalism which has held, among other things, that slavery is right because blacks are "naturally" suited to heavy labor, that abortion is wrong because it interrupts the "natural" course of the pregnancy, that euthanasia is wrong because it alters the "natural" time of death, that homosexuality is wrong because it is "unnatural" in the sense that it constitutes "the use of an organ for something other than it's intended purpose," and that airplanes are the work of the devil because humans don't "naturally" have wings. The deep ecologists have dispensed with the intent of God to figure out what the "natural course" of things is only to submit their own assurances that they know what it is.

Nothing in this debate is advanced by Callicott's talk of "bio-empathy," which he derives from what he argues to be a Humean moral subjectivism. He argues that the crucial insight of Hume is that altruistic impulses form as basic a part of our overall set of moral sentiments as do egoistic ones. These altruistic impulses, however, are extremely variable, given the influence of reasonable deduction, acculturation and increased scientific understanding. So, on this view, why can't our altruistic sentiments be extended to natural objects and even to whole ecosystems? The reason we can't do this is because altruistic empathy for another is impossible unless you know what that other entity feels, wants or has an interest in. I can certainly understand how I and other mammals have an interest in the environment not becoming inhospitable to mammalian 
life but I can't see at all that the environment has any stake in this matter-it will go on regardless of our fate.

Moreover, nothing is advanced by the turn toward very deep ecology reflected in the writings of people like Rolston, the Routleys and Shepard. This turn is given a sympathetic rendition by Callicott, who cites Alan Watts's claim that "the world is your body," Shepard's claim that "the skin is ecologically like a pond surface or a forest soil, not a shell so much as delicate interpenetration," Rolston's claim that "neither lake nor self has independent being.... Inlet waters have crossed this interface and are now embodied within me," and Capra's claim that "quantum theory... reveals a basic oneness in the universe.... The Cartesian partition between the I and the world...cannot be made...."12 Use might well be made in these musings of Parfit's work on personal identity. At any rate, the basic problem remains the same: I might well feel one with the world, but what does this part of me want? What would be good for it? To tell me that I $a m$ it is to simply leave me confused about what I feel about myself and, thus, to leave me confused about why I should care about anything. ${ }^{13}$ This sort of ecology is not merely deep; it is unfathomable.

\section{Notes}

${ }^{1}$ Mark Sagoff, "Animal Liberation and Environmental Ethics: Bad Marriage, Quick Divorce." $Q Q$ : Report from the Center for Philosophy and Public Policy 4 (Spring 1984).

${ }^{2}$ J. Baird Callicott, In Defense of the Land Ethic (Albany: SUNY Press, 1989), p. 32.

${ }^{3}$ Tom Regan, The Case for Animal Rights (Berkeley: University of California Press, 1983). See especially pp. 360-363.

${ }^{4}$ See his "Rights, Interests, Desires and Beliefs." American Philosophical Quarterly 16 (July 1979), pp. 233-39.

${ }^{5}$ Paul W. Taylor, "The Ethics of Respect for Nature." Environmental Ethics 3 (Fall 1981), p. 199

${ }^{6} \mathrm{Ibid}$.

${ }^{7}$ Stephen Clark, The Moral Status of Animals (Oxford: Clarendon Press, 1977).

${ }^{8}$ Robin Attfield, "The Good of Trees." The Journal of Value Inquiry 15 (1981), p. 43. Emphasis added.

${ }^{9}$ It must be noted that Frey and Attfield don't put much weight on the interests of nonsentients, and Taylor leans heavily in the direction of holism.
${ }^{10}$ That the beauty of nature is something that appears to presuppose a human aesthetic sense is recognized by John Rodman as a problem with Aldo Leopold's dictum that right is a matter of the preservation of the "integrity, stability and beauty of the biotic community." Rodman thinks that the term "beauty" ought to be replaced by something like "diversity." See Leopold's Sand County Almanac (New York: Oxford University Press, 1949) and Rodman's "Ecological Sensibility" (In VanDeVeer and Pierce, People, Penguins and Plastic Trees. Belmont: Wadsworth Publishing, 1986).

11 The historian Lynn White once argued that the responsibility for our current environmental insensitivity grew entirely out of Christian attitudes. As Jobn Passmore has pointed out, our condescension to nature bas its roots in the pre-Christian attitudes of the Greeks and Romans, and, moreover, Judeo-Christian thought has not been completely antithetical to an attitude of respect for nature. See Passmore's Man's Responsibility for Nature (London: Duckworth, 1980), Part One.

${ }^{12}$ See Callicott's In Defense of the Land Ethic pp. 112, 113 and 171.

${ }^{13}$ There is another problem with this very deep ecology (or, at least, with Callicott's sympathy for the position) inasmuch as his "bio-empathy" is based on an extension of our natural altruism, not a mere extension of our egoism as would result from a serious belief that the world really is my body.

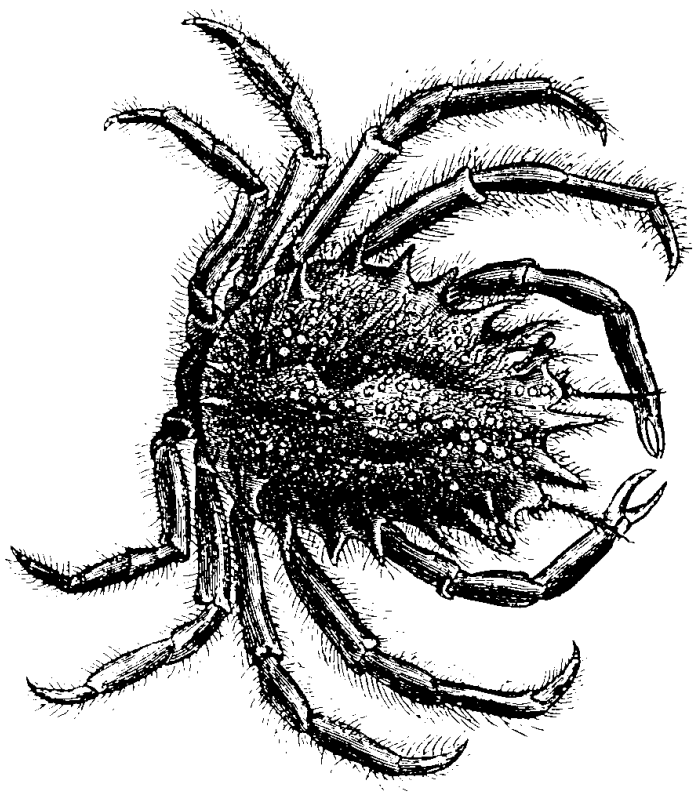

